\title{
The status of Her2 amplification and Kras mutations in mucinous ovarian carcinoma
}

\author{
Kuang-Leei Chang ${ }^{1}$, Ming-Yung Lee ${ }^{2}$, Wan-Ru Chao ${ }^{3^{*}+}$ and Chih-Ping Han ${ }^{3,4^{*}+}$
}

\begin{abstract}
Jayson GC et al. remarked in Lancet that nearly $100 \%$ of mucinous ovarian cancer cases have Kras mutation as well as a high frequency of Her2 amplification. Using the Abbott PathVysion Her2 DNA Probe Kit and Kras mutantenriched PCR Kits (FemtoPath ${ }^{\oplus}$ ), 21 samples of primary ovarian mucinous cystadenocarcinomas from Taiwanese patients were examined to determine the status of Her2 amplification and Kras mutations. Our results showed the Her2 amplification rates were $33.33 \%$, while the Kras mutation rates were $61.90 \%$. We present here our results in order to enlighten the readership that the $\sim 100 \%$ Kras mutant frequency and the high Her2 amplification rate reported by Jayson et al. may be too exaggerated to be applicable into all populations. Additionally, we report another 2 novel Kras mutations (A11V, V14I).
\end{abstract}

Keywords: Kras mutation, Her2 amplification, Mucinous ovarian carcinoma

\section{Main text}

We read with great interest the work by Jayson et al. in Lancet (Oct. 2014). The authors presented a comprehensive review of outstanding quality. They remarked that mucinous ovarian carcinoma has a nearly $100 \%$ human VKi-ras2 Kirsten rat sarcoma viral oncogene homolog (Kras) mutation as well as a high frequency of human epidermal growth factor receptor 2 (Her2) amplification [1]. However, we respectfully disagree with Jayson et al.'s opinion.

Literature reviews revealed that in mucinous ovarian carcinoma, the frequency of Her2 amplification/over-expression is estimated to be between 18 and 35\% [2], and the presence of human Kras mutations is 13 to 60\% [3-5]. This preliminary report aims to enlighten the readership that the $\sim 100 \%$ Kras mutant frequency and the high Her 2 amplification rate in mucinous ovarian carcinoma may be higher than what has been observed in other studies, including our own.

Briefly, genomic DNA was extracted from formalinfixed, paraffin-embedded tissue blocks of 21 cases of mucinous ovarian carcinoma. All the donors' identities have been permanently deleted. Abbott PathVysion Her2 DNA Probe Kit and the 2013 American Society of Clinical

\footnotetext{
* Correspondence: y1034@csmu.edu.tw; cshy762@csh.org.tw

${ }^{\dagger}$ Equal contributors

${ }^{3}$ Department of Pathology, Chung-Shan Medical University and Chung Shan Medical University Hospital, Taichung, Taiwan

Full list of author information is available at the end of the article
}

Oncology/College of American Pathologists (ASCO/CAP) breast cancer scoring methods were used to examine for Her2 FISH ratio. The Kras mutant-enriched polymerase chain reaction (PCR) Kits (FemtoPath ${ }^{\circ}$ ) and a following direct sequencing method were applied to analyze exon 2 of the Kras gene. The reason why we choose Kras exon 2 to analyze is because Kras gene mutations are mainly known to cluster in several hotspots, with exon 2 (codons 12 and 13) being most commonly affected [6-9].

The prevalence of Kras mutations and Her2 amplification within 21 Taiwanese mucinous ovarian carcinoma cases is shown in Table 1, which indicates that the amplification rate of Her 2 was $33.33 \%(n=7)$, while the mutation rate of Kras was $61.90 \%(n=13)$. Additionally, the rates of co-existing Kras mutations and Her2 amplification were $9.52 \%(n=2)$ (Table 1$)$. However, there was a lack of statistically significant association between Her2 amplification and Kras mutations $(p=0.057)$.

Of the 13 cases of mucinous ovarian carcinoma with Kras mutations, 12 cases had a single missense mutation, which was composed of G12V in 4 cases, G12D in 5 cases, G12A in 1 case and A11V in 2 cases. The remaining 1 case had triple missense mutations-A11V, G13N and V14I. Moreover, both A11V and V14I were novel discoveries, based on the Catalogue of Somatic Mutations in Cancer (COSMIC) database [10]. 
Table 1 The prevalence and relationship of Kras mutations and Her2 amplification in mucinous ovarian carcinoma

\begin{tabular}{llll}
\hline & $\begin{array}{l}\text { Her2 non-amplification } \\
n(\%)\end{array}$ & $\begin{array}{l}\text { Her2 amplification } \\
n(\%)\end{array}$ & $\begin{array}{l}\text { Total } \\
n(\%)\end{array}$ \\
\hline Kras wild type & $3(14.29)$ & $5(23.81)$ & $8(38.10)$ \\
Kras mutation & $11(52.38)$ & $2(9.52)$ & $13(61.90)$ \\
Total & $14(66.67)$ & $7(33.33)$ & $21(100.00)$ \\
$P$ value & $0.056^{\mathrm{a}}$ & & \\
\hline
\end{tabular}

$n$ (\%) number (percentage)

${ }^{\text {a }}$ Fisher's exact test

\section{Conclusion}

Both Her 2 amplification and Kras activating mutations are not mutually exclusive, which indicates that Her $2 /$ Kras/ mitogen-activated protein kinases (MAPK) is a crucial pathway in the carcinogenesis of mucinous ovarian neoplasms. Targeting this pathway seems to be a viable therapeutic option for patients with recurrent or advanced stage mucinous ovarian carcinoma. Treatment selection based on the molecular alterations of Her2 and Kras can possibly produce superior therapeutic effects compared with nonselective treatments. Additionally, functional impacts of these 2 novel Kras mutations (A11V, V14I) are still unknown; further studies using bioinformatics tools and molecular modeling are encouraged.

\section{Abbreviations}

ASCO/CAP: American Society of Clinical Oncology/College of American Pathologists; COSMIC: Catalogue of Somatic Mutations in Cancer; Her2: Human epidermal growth factor receptor 2 gene; ICH: International Conference on Harmonization; Kras: V-Ki-ras2 Kirsten rat sarcoma viral oncogene homolog gene; MAPK: Mitogen-activated protein kinases; PCR: Polymerase chain reaction

\section{Acknowledgements \\ This work was supported by Prof. Hao-Ping Liu, DVM, PhD, National Chung Hsing University and Chung Shan Medical University, Taichung, Taiwan (Grant: NCHU-CSMU-10501). We are very much thankful to Prof. Heung Tat $\mathrm{Ng}, \mathrm{MD}$, Female Cancer Foundation, Taipei, Taiwan, for his keen interest and valuable guidance. We are extremely grateful to Jennie Cheng, RN, PhD; Alexandra Ruan, MD; and Bernard A (HHS/OPHS) Schwetz, DVM, PhD, for their expertise and patience in English correction and helpful comments.}

\section{Funding}

Grant: NCHU-CSMU-10501.

\section{Availability of data and materials}

Please contact the author for data requests.

\section{Authors' contributions}

$\mathrm{KLC}$ and $\mathrm{CPH}$ provided the specimens and wrote the manuscript. MYL analyzed the data. WRC performed the experiments. All authors read and approved the final manuscript.

\section{Competing interests}

The authors declare that they have no competing interests.

\section{Consent for publication}

Not applicable.

\section{Ethics approval and consent to participate}

Our research was conducted in accordance with the International Conference on Harmonization $(\mathrm{ICH})$ guidelines and compliant with all applicable regulations for the protection of human subjects for research, including review and approval by the Institutional Review Board of the Chung-Shan Medical University Hospital, Taichung, Taiwan.

\section{Author details}

${ }^{1}$ Department of Emergency Medicine, Chung-Shan Medical University and Chung Shan Medical University Hospital, Taichung, Taiwan. ${ }^{2}$ Department of Statistics and Informatics Science, Providence University, Taichung, Taiwan. ${ }^{3}$ Department of Pathology, Chung-Shan Medical University and Chung Shan Medical University Hospital, Taichung, Taiwan. ${ }^{4}$ Department of Obstetrics and Gynecology, Chung-Shan Medical University and Chung-Shan Medical University Hospital, No 110, Sec 1, Chien Kuo N. Rd, Taichung 40201, Taiwan.

Received: 2 September 2016 Accepted: 27 November 2016

Published online: 28 December 2016

\section{References}

1. Jayson GC, Kohn EC, Kitchener HC, Ledermann JA. Ovarian cancer. Lancet. 2014:384:1376-88

2. Chao WR, Lee MY, Lin WL, Koo CL, Sheu GT, Han CP. Assessing the HER2 status in mucinous epithelial ovarian cancer on the basis of the 2013 ASCO/ CAP guideline update. Am J Surg Pathol. 2014;38:1227-34.

3. Li XS, Sun J, He XL. Expression of c-myc and mutation of the Kras gene in patients with ovarian mucinous tumors. Genet Mol Res. 2015;14:10752-9. doi:10.4238/2015.September.9.14.

4. Auner $V$, Kriegshäuser $G$, Tong $D$, et al. Kras mutation analysis in ovarian samples using a high sensitivity biochip assay. BMC Cancer. 2009;9:111.

5. Perren TJ. Mucinous epithelial ovarian carcinoma. Ann Oncol. 2016;27 suppl 1:153-7. doi:10.1093/annonc/mdw087.

6. Zinsky R, Bölükbas S, Bartsch H, et al. Analysis of Kras mutations of Exon 2 Codons 12 and 13 by SNaPshot analysis in comparison to common DNA sequencing. Gastroenterol Res Pract. 2010;2010:789363. doi:10.1155/2010/789363.

7. Prior IA, Lewis PD, Mattos C. A comprehensive survey of Ras mutations in cancer. Cancer Res. 2012;72:2457-67.

8. Bos JL. Ras oncogenes in human cancer: a review. Cancer Res. 1989;49: 4682-9.

9. Stolze B, Reinhart S, Bulllinger $L$, et al. Comparative analysis of Kras codon $12,13,18,61$, and 117 mutations using human MCF10A isogenic cell lines. Sci Rep. 2015;5:8535. doi:10.1038/srep08535.

10. Lee YJ, Lee MY, Ruan A, et al. Multipoint Kras oncogene mutations potentially indicate mucinous carcinoma on the entire spectrum of mucinous ovarian neoplasms. Oncotarget. https://www.ncbi.nlm.nih.gov/ pubmed/27888800. Advance Online Publications. 2016. doi:10.18632/ oncotarget.13449.

Submit your next manuscript to BioMed Central and we will help you at every step:

- We accept pre-submission inquiries

- Our selector tool helps you to find the most relevant journal

- We provide round the clock customer support

- Convenient online submission

- Thorough peer review

- Inclusion in PubMed and all major indexing services

- Maximum visibility for your research

Submit your manuscript at www.biomedcentral.com/submit
Biomed Central 